\title{
$\beta$-Cell Maturation and Identity in Health and Disease
}

\author{
Ciro Salinno ${ }^{1,2,3,4}$, Perla Cota ${ }^{1,2,3,4}$, Aimée Bastidas-Ponce ${ }^{1,2,3,4}$, Marta Tarquis-Medina ${ }^{1,2,3,4}$, \\ Heiko Lickert $1,2,3,4, *$ and Mostafa Bakhti $1,2,3, *$ (D) \\ 1 Institute of Diabetes and Regeneration Research, Helmholtz Zentrum München, D-85764 Neuherberg, \\ Germany; ciro.salinno@helmholtz-muenchen.de (C.S.); perla.cota@helmholtz-muenchen.de (P.C.); \\ aimee.bastidas-ponce@helmholtz-muenchen.de (A.B.-P.); marta.medina@helmholtz-muenchen.de (M.T.-M.) \\ 2 German Center for Diabetes Research (DZD), D-85764 Neuherberg, Germany \\ 3 Institute of Stem Cell Research, Helmholtz Zentrum München, D-85764 Neuherberg, Germany \\ 4 School of Medicine, Technical University of Munich, 81675 Munich, Germany \\ * Correspondence: heiko.lickert@helmholtz-muenchen.de (H.L.); mostafa.bakhti@helmholtz-muenchen.de \\ (M.B.); Tel.: +49-89-3187-3867 (H.L.); +49-89-3187-43153 (M.B.)
}

Received: 9 October 2019; Accepted: 29 October 2019; Published: 30 October 2019

\begin{abstract}
The exponential increase of patients with diabetes mellitus urges for novel therapeutic strategies to reduce the socioeconomic burden of this disease. The loss or dysfunction of insulinproducing $\beta$-cells, in patients with type 1 and type 2 diabetes respectively, put these cells at the center of the disease initiation and progression. Therefore, major efforts have been taken to restore the $\beta$-cell mass by cell-replacement or regeneration approaches. Implementing novel therapies requires deciphering the developmental mechanisms that generate $\beta$-cells and determine the acquisition of their physiological phenotype. In this review, we summarize the current understanding of the mechanisms that coordinate the postnatal maturation of $\beta$-cells and define their functional identity. Furthermore, we discuss different routes by which $\beta$-cells lose their features and functionality in type 1 and 2 diabetic conditions. We then focus on potential mechanisms to restore the functionality of those $\beta$-cell populations that have lost their functional phenotype. Finally, we discuss the recent progress and remaining challenges facing the generation of functional mature $\beta$-cells from stem cells for cell-replacement therapy for diabetes treatment.
\end{abstract}

Keywords: $\beta$-cell; maturation; postnatal; identity; dysfunction; dedifferentiation; transdifferentiation; senescence; SC- $\beta$-cells; diabetes

\section{Introduction}

Diabetes mellitus (DM) is a chronic condition characterized by impairment of blood glucose homeostasis, resulting in hyperglycemia and a series of secondary complications, such as cardiopathy, neuropathy, nephropathy, and retinopathy. There are two main forms of diabetes. Type 1 diabetes (T1D) is an autoimmune disease where insulin-producing pancreatic beta cells ( $\beta$-cells) are destroyed by the immune system. In contrast, insulin resistance and progressive dysfunction of $\beta$-cells characterize type 2 diabetes (T2D) [1,2]. Current treatments are only able to ameliorate diabetes symptoms by decreasing/normalizing the blood glucose levels without halting the causes of the disease. Administration of insulin remains the most common treatment for patients with T1D and the last treatment option for patients with T2D. However, insulin treatment is associated with some risk of hypoglycemic episodes, weight gain and increased incidence of cancer [3]. The only curative approaches are bariatric surgery for T2D [4] and transplantation of pancreatic islets of Langerhans from cadaveric donors, especially for T1D [5]. Unfortunately, this last approach is neither easily applicable nor permanent. First, the shortage of donor organs makes the transplantation option exclusively available to patients that fulfill a strict severity criterion. Second, the patients that receive the cadaveric 
islets are at risk of (auto-)immune-rejection, thus they are treated with immunosuppressive drugs, with an increased associated risk of infections and cancer [6]. Considering T2D as a possible reversible disease, alternative therapeutic strategies are being developed. Removing the main causes of the diabetic condition is at the base of the newest approaches, for example by removing glucotoxicity, one of the main driver of $\beta$-cell loss and identity in T2D [7]. Thus, it is possible to improve $\beta$-cell function by reestablishing cellular maturation and identity and to protect and regenerate dysfunctional $\beta$-cells during disease progression.

Theoretically, regenerative approaches are another alternative option for diabetes treatment that includes: (i) reestablishing or enhancing the healthy cellular phenotype and (ii) replacing the lost and/or dysfunctional cells. The first strategy focuses on finding drugs and small molecules (a) to restore the physiological signaling pathways lost in disease [8-10], (b) to remove the dysfunctional cells from the islets [11,12], or (c) ameliorate the micro-environmental conditions that sustain the impairment of $\beta$-cells [13-16]. The goal of this approach is to redirect the dysfunctional $\beta$-cells towards a healthy functional state. However, to target $\beta$-cells or specifically deliver drugs to these cells remains a major obstacle. The second strategy focuses on the screening of compounds to trigger $\beta$-cell neogenesis, transdifferentiation of non- $\beta$ islet cells towards $\beta$-cells or the endogenous expansion of existing $\beta$-cells [17-20]. Alternatively, great efforts are put together to replace $\beta$-cells by using stem cell derived $\beta$-cells (SC- $\beta$-cells) as source for transplantation [21-27]. These SC- $\beta$-cells should be fully functional similar to the endogenous mature adult $\beta$-cells, in order to be used for the clinical settings. So far, no differentiation protocol has achieved the generation of fully functional mature $\beta$-cells that present comparable glucose-stimulated insulin secretion (GSIS) to human adult islets. Over the past two decades, groundbreaking research has been carried on to decipher $\beta$-cell maturation process. These cells arise during embryonic development [28-30] with an immature phenotype [31-33]. After birth, a sequence of molecular and metabolic changes lead to $\beta$-cell maturation, which enables these cells to respond with an appropriate insulin release to fluctuating glucose levels. To fulfill their physiological function, $\beta$-cells actively preserve this maturation machinery that defines their functional identity. Numerous reports have shown the loss of $\beta$-cell maturation and identity in diabetic conditions [34-36]. Therefore, it is essential to understand the maturation process in detail in order to prevent the loss of maturity or restoring maturation state of those $\beta$-cell that lost their identity.

Recent studies have shown that not all $\beta$-cells acquire maturation at the same time. Furthermore, mature $\beta$-cells represent heterogonous populations in terms of phenotype and functionality. As there are excellent reviews on $\beta$-cell heterogeneity [37-42], here we focus on the current understanding of the mechanisms that regulate $\beta$-cell maturation and identity, in healthy and diabetic conditions. First, we summarize the characteristics (markers, functionality, and signaling pathways) that allow distinguishing immature and mature $\beta$-cells. Second, we provide an overview of what is currently known about the loss of $\beta$-cell identity and the three main phenotypes that have been identified in diabetic conditions: dedifferentiated, senescence, and transdifferentiation of $\beta$-cells. We further summarize the state of the art of therapeutic approaches to reestablish the mature phenotype or to replenish the $\beta$-cell mass. Finally, we provide a short overview of the most recent advancements regarding the differentiation protocols to generate functional mature SC- $\beta$-cells in vitro. A better understanding of the $\beta$-cell differentiation and maturation as well as deciphering the dysfunctional $\beta$-cell states arising in disease can lead future research to develop better therapeutic strategies and even permanent disease modification for patients with diabetes.

\section{Embryonic Development: Rise of $\beta$-Cells}

In rodents, endocrine cells are formed at two stages or transitions during embryonic development. At the primary transition (E9.0-E12.5) the main differentiated endocrine cells are $\alpha$-cells. In contrast, during secondary transition (E12.5-E15.5) all other endocrine cell types including $\beta$-cells are formed $[32,33,43,44]$. Notably, in humans, it is thought that only the secondary transition exists and that gives rise to all hormone-secreting endocrine cells [45]. In rodents and humans, 
endocrinogenesis initiates with the emergence of the mitotic endocrine progenitors that are marked by the expression of low levels ( $\mathrm{Ngn} 3^{\text {low }}$ ) of the transcription factor (TF) neurogenin 3 (Neurog3, Ngn3). The increase in expression levels of Ngn3 results in generation of low-cycling endocrine precursors $\left(\mathrm{Ngn} 3^{\text {high }}\right)[46,47]$. Then the endocrine precursors generate E26 transformation-specific transcriptional factor (Fev)-expressing cells, which do not yet express hormones [48]. Further differentiation of $\mathrm{Fev}^{+}$ cells results in the acquisition of secretory machinery components and hormones to form differentiated endocrine cells $[28,48]$. How the different endocrine cell types are generated from a single progenitor pool is not well understood yet. The status of pancreatic epithelium and developmental timing of endocrine differentiation are among possible mechanisms [28,49,50]. Moreover, it has been suggested that endocrine precursors are unipotent and cell fate commitment towards specific endocrine subtype is already determined at this stage [46,51]. More evidence comes from a recent study showing that endocrine precursors are transcriptionally heterogeneous and they differentially express a set of specific signature genes that might define their fate towards $\alpha$ - or $\beta$-cells [28]. However, most of these signature genes are poorly characterized and future studies should uncover their possible function during endocrine lineage allocation. Recent studies showed how mouse and human pancreas follow markedly different paths of development [52,53]. In conclusion, further studies are required to define the expression of these signature genes in humans and whether they have evolutionary conserved function during endocrinogenesis.

Endocrine differentiation is tightly regulated by dynamic changes in gene regulatory networks (Figure 1). The master regulator of endocrine progenitor-precursor (EP) formation and differentiation is Ngn3. This TF is transiently expressed in EPs and its function is indispensable for endocrine cell formation [54,55]. As differentiation proceeds, the generation of different endocrine cell types relies on the expression of distinct specific TFs. For instance, higher expression levels of Arx and Pax4 favor formation of $\alpha$ - and $\beta / \delta$-cells, respectively [56]. Moreover, differentiation toward $\beta$-cell fate depends on the expression of several other TFs, such as Foxa2, Pdx1, Nkx6-1, Neurod1, Nkx2-2 and Mnx1 [57-60]. Although most of these TFs have been shown to be expressed during human $\beta$-cell formation [45,61], their expression pattern and function have not been studied as detailed as in rodents. In contrast to rodents, NKX2-2 is only expressed in human endocrine cells but not in pancreatic progenitors. Furthermore, GATA6 is necessary only for the formation of the human but not rodent pancreas $[45,62]$. Additionally, human $\beta$-cells co-express MAFA and MAFB, though MAFA is expressed in juvenile human $\beta$-cells, and there is no consensus about its expression in SC- $\beta$-cells $[43,63,64]$. Although these studies have shed light on the expression pattern of some TFs during human endocrinogenesis, deeper analyses are required to uncover the similarities and differences between mouse and human endocrine cell formation. Combining ex vivo modeling systems such as 3D cyst or organoids $[30,65]$ with single-cell genomic and transcriptomic profiling will help to provide a more comprehensive picture of gene regulatory changes during human endocrinogenesis. 


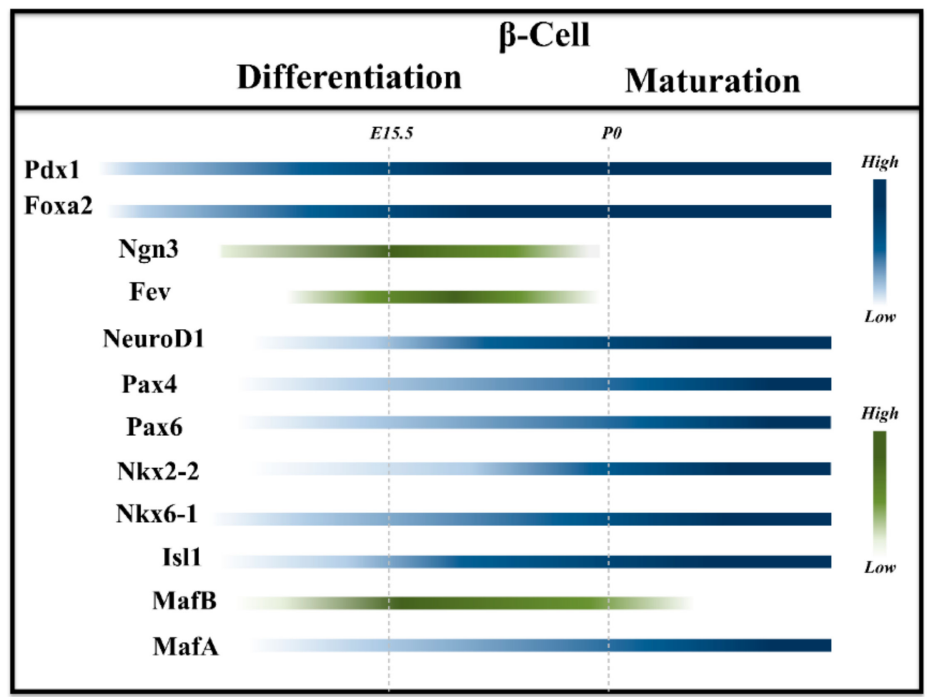

Figure 1. Pivotal TFs regulating $\beta$-cell differentiation and maturation in rodents. Schematic representation of the most prominent TFs involved in endocrine induction, lineage specification, differentiation and maturation of $\beta$-cells. Gradient colors represent the expression levels during the process. Green colored lines indicate the TFs that are transiently expressed, while the blue ones are those that remain expressed also in adulthood.

\section{Postnatal Development: Road to Maturity}

Most of our current understanding of $\beta$-cell maturation is derived from rodent studies. In mouse, embryonic $\beta$-cells are described as immature, highly proliferative and unipotent albeit still plastic. Although at this stage $\beta$-cells present insulin granules and display high basal insulin, until which extent they can secret insulin is not well characterized [31,32]. After birth, $\beta$-cells are abundant and organized in clusters, so called proto-islets $[33,66]$. However, at this stage these cells do not yet acquire a mature phenotype to properly secret insulin in response to glucose levels [67]. The events that conclude the maturation process occur in postnatal stages. $\beta$-cells follow a biphasic pattern of maturation [68], possibly adapting to the neonatal type of diet. The first two weeks after birth define a first maturation wave [31]. Here, it is possible to observe a general increase of the endocrine mass, implying that $\beta$-cells are still proliferative, characteristic that is progressively lost [69]. During this stage, $\beta$-cells acquire all the TFs and machinery necessary for the establishment of the adult $\beta$-cell identity (Figure 1 ). The second wave of maturation coincides with the third week of life and the weaning period [70]. During this time, $\beta$-cells differentially regulate metabolic pathways defining the mature functional landscape [11]. For simplicity, we describe and divide the postnatal maturation process according to three aspects: (i) markers, (ii) functionality, and (iii) signaling pathways. Clearly, the three aspects are tightly connected to one another, contributing to the complex identity of mature $\beta$-cells.

\subsection{Markers}

At birth, all $\beta$-cells possess signature genes, which are important for the establishment and maintenance of $\beta$-cell identity: Nkx2-2, Pdx1, Nkx6-1, and Neurod1 are some examples. In the past years, several markers have been characterized in order to identify sub-clusters of $\beta$-cells during development, healthy or diseased states (Figure 2). Urocortin3 (UCN3) is a secreted peptide that is expressed at low levels in $\beta$-cells already before birth. Within the following 2 weeks, almost all $\beta$-cells possess high levels of this peptide [31]. Thus, the acquisition of Ucn3 marks the early phase of postnatal maturation. The role of Ucn3 is still not completely known. One study linked Ucn3 activity with somatostatin-dependent negative feedback of insulin secretion [71]. Of note, UCN3 is expressed, in humans, in both $\alpha$ - and $\beta$-cells and in human embryonic stem cell (hESC)-derived endocrine cells upon transplantation [72]. Similarly, a member of Synaptotagmin (Syt) family, Syt4, is upregulated 
during the postnatal stages. The role of this protein is fundamental for the reduction of calcium sensitivity, high in immature $\beta$-cells, that directly regulates the exocytosis of insulin granules [73]. Contrary to Ucn3 and Syt4, Neuropeptide Y (NPY) marks immature $\beta$-cells in both mouse and human [74]. In mouse, the levels of Npy drop dramatically in the first two weeks of life, and is barely detectable at one month, overlapping with the first phase of $\beta$-cell maturation and acquisition of functionality. The role of this neuropeptide is still not fully understood. Some evidence suggests that it might contribute to the maintenance of the immature phenotype, promoting proliferation and high basal insulin secretion $[74,75]$.

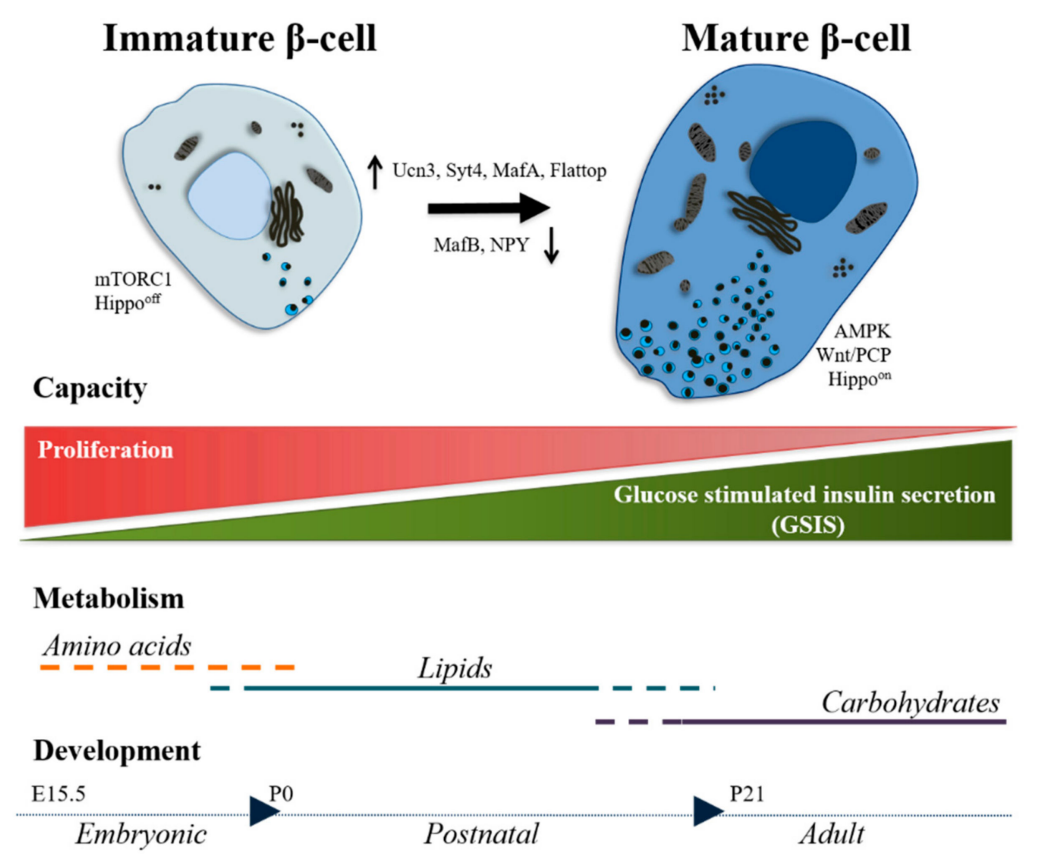

Figure 2. $\beta$-cell maturation process. Simplified representation of the complex group of events leading to the $\beta$-cell maturation in rodents. In the top part of the figure, $\beta$-cells in their immature ad mature stages, characterized by key signaling pathways. Between the two cells, the prominent TFs and markers that are differentially regulated in the maturation process are shown. Below the two most significant capacities are mentioned, proliferation for immature $\beta$-cells and GSIS for mature $\beta$-cells. Following, the type of metabolisms affecting the maturation stages are mentioned. At the bottom, the timeline of the $\beta$-cell maturation process is indicated.

Among TFs, the Maf family is important for the establishment of $\beta$-cell identity and functionality [76]. In rodents, MafB is highly expressed in embryonic $\beta$-cells and is rapidly downregulated after birth. During this period, MafA progressively substitutes MafB and regulates the expression of genes, such as Glut2, GLP-1 receptor, prohormone convertase- $1 / 3$, and pyruvate carboxylase that characterize glucose sensing and insulin secretion [77-79]. Thus, the switch from MafB (which remains expressed in $\alpha$-cells) to MafA is crucial and characterizes the late phase of postnatal maturation [76,80]. Different from rodents, in humans, MAFB remains highly expressed in adult $\beta$-cells $[81,82]$. Along this line, MAFB knockdown results in dysregulation of $\beta$-cell transcriptional program, providing an important proof of non-redundancy function of the two TFs in humans [83]. Future studies should address this peculiarity of human $\beta$-cells, in order to understand the mechanisms that sustain MAFB function.

Another marker recently characterized is Flattop (Fltp), a Wnt/Planar Cell Polarity (PCP) effector protein [84]. This marker has been exploited to distinguish an immature pool (Fltp ${ }^{-}$) and terminally mature $\left(\right.$ Fltp $\left.^{+}\right) \beta$-cells. The Fltp ${ }^{-} \beta$-cells are characterized by a higher proliferation rate (both in homeostasis and pregnancy) and differential mRNA expression of GPCR, Wnt and MAPK signaling components. The Fltp ${ }^{+}$cells feature a higher expression of $\beta$-cell functional genes (i.e., Slc2a2, Nkx6-1, Ucn3, MafA, etc.), an increased number of mature secretory granules, enhanced mitochondrial 
physiology and higher static GSIS [85]. Thus, the study has linked Wnt/PCP activity to cell cycle exit and therefore acquisition of functional maturity. Similarly, in humans, the surface markers ST8SIA1 and CD9 distinguish four antigenically subgroups of $\beta$-cells in adult islets. These groups differ in gene expression profiles and functionally. Although all groups express comparable levels of INS, PDX1, NKX6-1, and MAFA, they differentially express more than 200 genes including GLUT2, PPP1R1A, SUR2, and G6PC2 that are involved insulin secretion. These differences are reflected in their functionality since the group of $\beta$-cells lacking both surface markers show the lowest basal insulin secretion and the highest GSIS. Finally, the ratio of the four subpopulations changes in diabetes. It is of great interest to understand what are the determining mechanisms that drive this change [86]. Of note, the heterogeneity of $\beta$-cells seems to be an intrinsic and thus relevant feature. This topic has been broadly described elsewhere and therefore, we have not extensively discussed it in this review [37,38,40,42]. Altogether, an increased number of studies have adopted a series of novel markers to distinguish $\beta$-cell subpopulations, underlying different physiological attributes. Understanding the dynamics of acquisition and maintenance of these markers is a powerful tool to assess the pathophysiological state of $\beta$-cells, in health and diseases, and to determine the efficacy of therapeutic treatments for diabetes.

\subsection{Functionality}

The presence or absence of certain markers is associated with functional characteristics that distinguish immature from mature $\beta$-cells. However, not all $\beta$-cells develop at the same time and some remain with distinct immature characteristics during adult life. This heterogeneity mostly develops during the perinatal age and it is maintained, albeit debunked, in adulthood. Several studies [85-88] have demonstrated the existence of different types of $\beta$-cells within the islets. The ratio of the different subpopulations usually shifts under metabolic stress or diabetes progression. Therefore, the maintenance of the $\beta$-cell heterogeneity does not seem to be random but contextual. In this section, we describe the most prominent functional features of $\beta$-cells during maturation. The proliferative capacity of $\beta$-cells, both in mouse and human, is strictly confined to the early stages of life (for more information see reviews [89-91]) (Figure 2) or to high demanding physiological conditions (such as pregnancy [92]). This idea has been recently strengthened by isotope labeling experiments, in which the basal bodies of primary cilia of $\beta$-cells remain unchanged for long period of time, thus proving the absence of cell cycle [93]. On contrary, $\beta$-cell proliferation is increased upon insulin resistance in obesity [94]. The cell cycle exit coincides with a series of molecular changes in $\beta$-cells that lead to the terminal maturation process [95-97]. In healthy conditions, only a small pool of $\beta$-cells retain low proliferative capacity, which is linked to an immature functional phenotype [86]. Thus, the reduced proliferative capacity is one of the strongest features of immature $\beta$-cells. Understanding how to manipulate the cell cycle in these cells is foreseen as a possible therapeutic treatment option to restore the lost $\beta$-cells mass.

The glucose stimulated insulin secretion (GSIS) is the best functional characteristic of mature $\beta$-cells. The GSIS is defined as the capability of $\beta$-cells to secrete an appropriate amount of insulin in response to proportional extracellular glucose stimuli. The GSIS is the sum of a multitude of cellular processes $[98,99]$, such as sensing of glucose, which enters $\beta$-cells via the specific glucose transporter (Glut2 for rodents, GLUT1 for humans). The expression of this transporter is one of the main functional characteristics that distinguish a mature (even if not fully mature) from an immature or diseased $\beta$-cells (Figure 2). After entering into $\beta$-cells, glucose is quickly converted into glucose-6-phosphate (G6P), which is redirected in the two main metabolic processes: glycolysis and oxidative phosphorylation. The events result in the production of ATP and other molecules that also serve as coupling factors. In this context, the mitochondria biogenesis and metabolisms play a crucial role in the development of the mature GSIS, since it has been proved that this organelle actively participates in the control and enhancement of insulin secretion. The final goal of the actions that take place in $\beta$-cells after the entrance of glucose is to induce the exocytosis of the cytoplasmic insulin granules. In order to do so, a pattern of electrical signals needs to be generated by the fast activation and deactivation of ions 
channels. The increase of the ATP/ADP ratio induces the closure of the $\mathrm{K}_{\mathrm{ATP}}$ channels that generates a depolarization of the plasma membrane. This triggers the action potential that opens the voltage-gated $\mathrm{Ca}^{2+}$ channels. The influx of this ion has the fundamental role to induce the exocytosis of the insulin vesicles. Many other factors can influence insulin secretion, as the amino acids arginine and leucine, or the hormone GLP-1 (for more details see reviews: [100-103]). All of the above mention features are tightly connected to each other, creating an extremely complex molecular network that is developed during the postnatal maturation process.

Comparative studies among different ages showed that the biological processes beneath the GSIS are activated only during the postnatal development $[104,105]$. In fact, the neonatal islets are considered as "leaky", meaning that $\beta$-cells secrete high insulin levels in response to low glucose stimuli (defined as high basal insulin secretion) $[31,106]$. Once acquired key components, such as Syt4, the exocytosis of insulin granules is less sensitive to low calcium levels, therefore $\beta$-cells secrete low insulin concentrations at low glucose levels and high insulin concentrations, at high glucose levels, in a biphasic fashion [107]. Recent studies addressed the topic of the functional heterogeneity in healthy adult islets, in zebrafish, mice, and humans. It has been shown that putative pacemaker $\beta$-cells, called hub or leader cells, are heavily connected with neighbor cells and through rhythmic calcium oscillations coordinate the electrophysiological response to glucose stimuli $[87,108,109]$. Thus, the presence of hub or leader cells has a major contribution to the collective regulatory behavior of islets in secreting insulin. Of interest is the understanding of when these hub cells arise and how this functional dominance is established.

\subsection{Signaling Pathways}

A complete understanding of the $\beta$-cell maturation process has to include the knowledge of the pathways that are differentially regulated (Figure 2). The mTOR (mammalian target of rapamycin) pathway orchestrates a plethora of cellular activities including proliferation and growth [110] in response to external stimuli such as nutrients or survival signals. This pathway is also the predominant signaling in charge of the early postnatal $\beta$-cell development. The beginning of oral feeding after birth, thus the transition from blood supplied nutrition type to an enteral one, induces the upregulation of the mTOR signaling pathway. According to Sinagoga and colleagues, the mTORC1 complex contributes to the progression of the functional maturation, while the mTORC2 branch regulates islet architecture and mass [111]. Other studies also confirmed that the mTORC1 signaling significantly affects the glucose metabolism [112] and therefore the advancements in the tuning of GSIS.

Another pathway that has recently gained attention in the context of $\beta$-cell maturation is AMPK (5' AMP-activated protein kinase) signaling. The AMPK complex is a cellular energy and stress sensor, responding to the available intracellular levels of ATP [113]. This pathway is already the target of diabetes treatments and it is known to be involved in the regulation of $\beta$-cell mass and insulin secretion, among others $[114,115]$. Previous studies have shown how weaning, thus the switch from high-fat milk to high-carbohydrate food, triggers the $\beta$-cell maturation enhancing oxidative phosphorylation at high glucose levels while blunting it at basal glucose levels [70]. In a similar fashion, Jaafar and colleagues have demonstrated how the weaning process induces the activation of the AMPK signaling, which antagonizes and inhibits the mTORC1 complex. By continuous feeding of litters with milk-based gavages, longer after weaning age, they maintained neonatal levels of mTORC1 in $\beta$-cells. Thus, AMPK signaling is at the center of the second phase of maturation, inhibiting the mTORC1 pathway and enhancing mitochondrial biogenesis and oxidative metabolism [11]. On the same line, the ERR $\gamma$ transcriptional network has been proved to induce the metabolic transition in the postnatal age that determines the acquisition of the mature $\beta$-cell functionality, among which the typical GSIS [116].

Wnt signaling pathway is known to be fundamental for the endocrinogenesis process during the embryonic development [117-119]. A recent study has also engaged the use of a Wnt/PCP effector protein, Fltp, to demonstrate the association between non-canonical Wnt signaling and the $\beta$-cell maturation phenotype [86]. However, the molecular mechanisms through which Wnt/PCP 
regulates the maturation process have not been deciphered yet. One possible scenario is that through rearrangement of cytoskeleton components and $\beta$-cell polarity [120], non-canonical Wnt signaling impacts islet compaction and architecture to determine a higher order of tissue organization, required for $\beta$-cell function [42,121]. As supporting evidence, the treatment of mouse islets and Min6 cells with non-canonical Wnt ligands, Wnt5a, increases the expression of maturation markers Ucn3, Nkx6-1 and Glut2. Furthermore, the treatment of EndoC- $\beta$ H1 human cell line and human islets with the ligands Wnt4 and Wnt5a respectively upregulates JNK activity and improves GSIS [86]. Similarly, secreted frizzled-related protein-5 (Sfrp5) reduces the proliferation rate and improves the GSIS in Ins1 cells through upregulation of JNK [122]. It should be noted that the function of non-canonical Wnt signaling in the acquisition of the mature phenotype could partially be indirect, via inhibition of the cell cycle. Despite these studies, the remained challenge is to decipher the interplay between the abovementioned signaling pathways including mTOR, AMPK and Wnt signaling during $\beta$-cell maturation. Additionally, it is possible that other signaling pathways such as Hippo signaling also play a role in establishment of the mature $\beta$-cell phenotype [123]. Detailed analysis of signaling pathways involved in $\beta$-cell maturation might provide novel therapeutic targets to restore the function of $\beta$-cells in diabetes and the implementation of novel steps for the in vitro SC- $\beta$-cell differentiation.

\section{Diabetic Conditions: $\beta$-Cells Derail}

$\beta$-cell dysfunction is a hallmark of several metabolic disorders, such as diabetes and it is characterized by the lack of function and loss of identity [34-36]. Oxidative stress, high levels of glucose and lipids, inflammatory cytokines, and altered gene expression represent unhealthy environments and are only among the causes of $\beta$-cell dysfunction [124]. Moreover, $\beta$-cells appear to acquire a level of plasticity in response to particular stressful environments provided, in this case, by T1D or T2D. Here, we aim to provide an overview of the different $\beta$-cell subpopulations or states reported in disease: dedifferentiated, transdifferentiated and more recently senescent $\beta$-cells.

\subsection{Dedifferentiated $\beta$-Cells}

A very well described feature of $\beta$-cells during diabetes is their loss of functional mature identity (Figure 3) [125]. A number of diabetic mouse models and human samples have been used to identify the factors that force $\beta$-cells to lose their mature features under stressful environments (such as glucotoxicity and lipotoxicity) [126-133]. The term "dedifferentiation" has been assigned to the reported dysfunctional $\beta$-cells, based on the idea that these cells "return" to a progenitor-like state $[130,131]$. For example, $\beta$-cells lacking the TF FoxO1 were found to express markers (i.e., Ngn3) that are specific to endocrine progenitor cells [130]. In accordance with these data, the downregulation of the TFs NKX6-1 and FOXO1 has been shown in human islets from patients with T2D [134]. In a similar fashion, gastrin, a hormone that is only present during embryonic development, was also expressed in T2D mouse models and human diabetic $\beta$-cells, highlighting $\beta$-cell immature phenotype under diseased conditions [126]. Very surprisingly, in NOD T1D mouse model, an immature surviving $\beta$-cell population was also identified. These cells were dysfunctional with reduced granularity, lower expression of mature signature genes (Glut2, ChgA, Pdx1, MafA, Ins2), increased proliferative capacity, higher expression of Ngn3 and increased aldehyde dehydrogenase (Aldh) activity [135]. Furthermore, a surviving $\beta$-cell group with similar immature phenotype has been observed in human patients with long standing T1D [136]. These studies suggest that losing the mature phenotype, by proliferation or other dysfunctional mechanisms, might improve the survival of $\beta$-cells. 


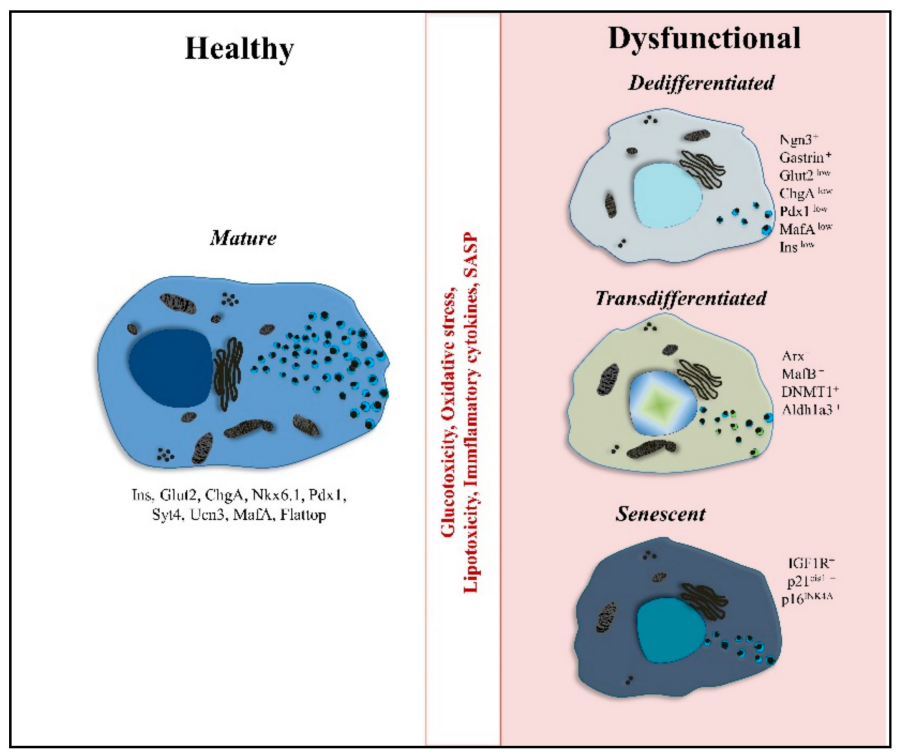

Figure 3. Altered $\beta$-cell phenotypes in diabetes. Schematic representation of $\beta$-cell described phenotypes as a response to diabetic environments. On the left side, a healthy mature $\beta$-cell is shown, in the middle box, disease stressors that induce changes in $\beta$-cell phenotype are mentioned, on the right side, summary of the three $\beta$-cell phenotypes observed in diabetes: immature/dedifferentiated, transdifferentiated and senescent, with each of the different phenotypes depicting the up- or down-regulation of key markers.

Studies aiming to understand the mechanisms of maintenance of $\beta$-cells maturity uncovered a disease mechanism involving Pdx1. In one study, the disruption of the Pdx1 auto-regulatory loop leads to hyperglycemia [137]. In the second, a similar phenotype has been detected by the disturbance of the Pdx1 cooperative function with Foxa2 [138]. Under similar glucotoxic conditions (observed in mouse and human $\beta$-cells under diabetic condition), a functional link between GSK3 and Pdx1 was described. Highly active GSK3 phosphorylates Pdx1 causing its degradation, impairing the expression of insulin and Glut2 as well as insulin secretion [139]. Furthermore, Jafaar and colleagues observed in diabetic conditions a metabolic switch, in which $\beta$-cells downregulate AMPK to upregulate mTORC1, typically observed in immature $\beta$-cells before weaning. Their data also reported that this same switch was recapitulated in samples from patients with T2D [11].

Dedifferentiated $\beta$-cell formation, establishment, and function under hyperglycemic conditions (glucotoxicity) is still a matter of study. In this regard, it has been demonstrated that just by removing the hyperglycemic condition these dedifferentiated $\beta$-cells reacquire a mature phenotype [126,131]. Along this line, insulin therapy of diabetic mice not only results in the expression of insulin itself together with other maturity markers like Pdx1, MafA and Nkx6-1 [131] but also eliminates gastrin expression [126]. Likewise, implementing fasting mimicking diet (FMD) cycles to diabetic mice reactivate FoxO1 in islets with subsequent expression of Ngn3 and expansion of the $\beta$-cell mass [140]. Furthermore, by administration of a GSK3 inhibitor to diabetic islets from T2D human donors, PDX1 functionality and GLUT2 expression were reinstated, making the islets capable to respond appropriately to glucose stimuli and removing glucotoxicity [139]. Thus, by pharmacological or dietary intervention it is possible to halt and ameliorate diabetes by reestablishing the mature $\beta$-cell phenotype.

It has been strongly demonstrated that the reduction of $\beta$-cell mass is largely caused by apoptosis [136,141-144]. However, the discovery of $\beta$-cell plastic capacity in disease expanded the horizon where $\beta$-cell loss of identity under diabetic conditions $[34,131,145,146]$ also contributes to $\beta$-cell mass reduction. Evidently, there is a mechanism that enhances $\beta$-cell plasticity as a response to the stressful-glucotoxic diabetic environments $[130,131]$, possibly acting as protective. However, understanding whether dedifferentiation is time or severity-dependent process is part of the missing pieces to decipher the full dedifferentiation-plastic mechanism. Finding the key pathways, molecules 
or endogenous stimuli will provide information for pharmacological treatment that could target and restore dysfunctional $\beta$-cells to a functional state.

\subsection{Polyhormonal Cells and Endcorine Cell Transdifferentiation}

Ectopic expression of key TFs and hormones specific for other endocrine cell types [147] indicates the plasticity of $\beta$-cells to differentiate toward other endocrine cell types (Figure 3) [148]. Evidence of ectopic expression of other hormones in $\beta$-cells comes from a mouse model with impaired insulin secretion and glucose intolerance caused by the lack of Nkx2-2 (TF needed for maintaining mature $\beta$-cell identity). Here, $\beta$-cells express insulin-somatostatin, insulin-glucagon or even just an alternative hormone and present a polyhormonal feature [149]. The appearance of polyhormonal $\beta$-cells together with reduced levels of Ucn3 (maturation marker) in postnatal stages were identified in a hyperglycemic mouse model caused by the interrupted interaction of FoxA2 and Pdx1 TFs [138]. In this regard, $\operatorname{Pdx} 1$ has been previously reported to be indispensable for the maintenance of $\beta$-cell identity, mainly by repressing the $\alpha$-cell program $[147,150]$. Hence, the reduction of Pdx1 activity might result in $\beta$-cell transdifferentiation to $\alpha$-cell fate. Interestingly, in samples from longstanding patients with T1D, non- $\beta$ endocrine cells show the presence of extremely low, still detectible, levels of insulin and variable levels of the key $\beta$-cell markers PDX1, NKX6-1, GLUT1, and PC1/3. Therefore, it seems that in extreme conditions, polyhormonal cells can arise as survival mechanisms and might pinpoint to a "natural" transdifferentiation process [133]. In accordance with the abovementioned work, another study showed the existence of PDX1-expressing $\alpha$-cells (glucagon positive cells) in biopsies from patients with T1D. The authors speculated that these are exhausted $\beta$-cells, transdifferentiated towards the $\alpha$-cell fate under extreme conditions [151]. These changes in identity might hide the cells from the immune system and prevent the onset or progression of the disease, as shown in another study in which by inducing proliferation and thus maintaining the immature features of $\beta$-cells, it was possible to prevent the progression of T1D in NOD mice [152].

The reverse process of transdifferentiation towards $\beta$-cells has been an extremely attractive alternative to replenish or restore $\beta$-cells, considering that this already happens under completely $\beta$-cell mass ablation $[147,153]$. In a recent elegant study, isolated $\alpha$-cells from human samples were genetically stimulated for the ectopic expression of the $\beta$-cell TFs PDX1 and MAFA. These cells were then transplanted to diabetic mice and not only were they able to produce insulin, but also to reduce hyperglycemia, shedding light on a different regenerative approach $[154,155]$. Further, in-depth analysis of $\alpha$ - to $\beta$-cell transdifferentiation was studied by downregulating two $\alpha$-cell signature genes, Arx and DNA methyltransferase 1 (DNMT1). With those modifications, $\alpha$-cells were able to activate the machinery that drives $\beta$-cell fate in mice [35]. Transdifferentiation under a challenging condition (diabetes) seems to be more of an attempt to maintain homeostasis in the system. The fact that $\beta$-cells have plasticity to the extent of transdifferentiation, opens up opportunities for regenerative therapies. The challenge with transdifferentiation strategies is always in the translatability to clinical models, finding the right combination of TFs and/or uncover the right efficiency and sustainability [155].

\subsection{Senescence}

Recent studies have clarified that $\beta$-cells undergo a process of senescence during the physiological aging process (Figure 3). Markers as IGF1R, p16ink4a, p53BP1, and $\beta$-galactosidase made possible to observe signs of premature aging and the accumulation of senescent cells in the islets of Langerhans, with reduced functionality if compared to non-senescent cells [156]. The appearance of a premature senescent $\beta$-cell subpopulation independent of the aging process has been also found under hyperglycemic and hyperinsulinemic conditions $[156,157]$. These subpopulations present downregulation of $\beta$-cell identity genes (MafA, Nkx6-1, and Pdx1) and upregulation of "disallowed genes" (as Cat and Ldha), together with a senescence-associated secretory phenotype (SASP) [12]. Interestingly, metabolic stress (glucotoxicity) was reported to speed up the appearance of senescent $\beta$-cells and loss of $\beta$-cell identity [156]. Similarly, a senescent phenotype, before the establishment of hyperglycemia and $\beta$-cell 
death, was observed in islets from NOD mice and patients with T1D [157]. The authors suggest that the inflammatory environment around the islets might be one mechanism at the base of $\beta$-cell senescence and SASP. Furthermore, the accumulation of these cells, that fail to be cleared out by the immune system, contributes to the disease progression by promoting activated immune cells infiltration and affecting the neighbor $\beta$-cell functionality [157]. Nonetheless, senescent dysfunctional $\beta$-cells from insulin resistant mouse models and T1D models (NOD mice) are capable of changing their phenotype into functional and mature upon the exposure to senolytic drugs. Here, $\beta$-cells downregulate senescent markers (p21cis1 and p16ink4a) and decrease islet indices of aging and SASP, alleviating the metabolic burden [12]. Overall, this new senescent subpopulation strengthens the idea that there must be a mechanism of $\beta$-cell remodeling that is triggered by the environment provided by the diabetic conditions (T1D and T2D). This senescent population was recently found to be present in disease. More needs to be understood in order to know their penetrability and if targeting these cells with senolytic molecules could be a long-lasting solution for diabetes treatment.

In conclusion, the above-mentioned studies highlight 2 key points in $\beta$-cell identity: (i) evidence of $\beta$-cell plasticity [158] when exposed to a diabetic environment (hyperglycemia, hyperinsulinemia) and ii) their capacity to return to a mature identity and functional phenotype. Thus far, immature, senescent and transdifferentiated $\beta$-cell subgroups have been described in diseased conditions. However, there are still some gaps in this area such as i) how healthy and ill $\beta$-cells coexist, (ii) how they influence each other in the same islets/pancreas, and iii) what are the mechanisms that determine when $\beta$-cells dedifferentiate, transdifferentiate or senesce under disease conditions. Hence, systematic snapshots of known $\beta$-cell subpopulations during $\beta$-cell maturation and under disease progression will answer some of these questions.

\section{5. $\beta$-Cell Differentiation Protocols: How to Make “Real" $\beta$-Cells}

The possibility to differentiate stem cells towards any cell type has opened up an entirely new field for regenerative medicine [159]. The idea to use SC- $\beta$-cells for transplantation purposes is fascinating and could potentially help millions of people living with diabetes. Pioneer works from different labs [24-27] allowed to differentiate iPSCs into $\beta$-like cells. Despite the presence of signature genes characterizing the $\beta$-cell lineage (PDX1, NKX2-2, NKX6-1, and INS), these protocols have not achieved a functional maturity with a reliable expression of MAFA and human-like dynamic GSIS and in addition a consistent number of poly-hormonal cells are still detectable in the latest stages.

Several recent studies have attempted to improve the differentiation protocols to achieve mature SC- $\beta$-cells. For example, Velazco-Cruz and colleagues obtained SC- $\beta$-cells with improved dynamic glucose response by i) reducing the differentiating cluster size, ii) manipulating the TGF- $\beta$ signaling, and iii) depriving the differentiation medium of several components, among which was the serum [64]. Alternatively, Nair and colleagues applied an additional step of aggregation of sorted immature SC- $\beta$-cells, in order to improve the functionality of these cells. The authors show that with this step it is possible to emulate some events of the postnatal development that leads to an improved functionality due, among others, to a metabolic maturation of mitochondria [160]. Alagpulinsa and colleagues, instead, focused on the possibility of transplant SC- $\beta$-cells together with encapsulation of alginate and CXCL12, which inhibits the fibrotic reaction post-transplant and ensure immune-protection and long-term survival of the graft [161]. Finally, Veres and colleagues clearly mapped, via single cell RNA sequencing (scRNA-seq), each stage of their differentiation protocol, dissecting for each stage of differentiation the milestones to reach islet-like cells [162,163]. Similarly, Alvarez-Dominguez and colleagues have recently mapped the epigenetic landscape of each differentiation step towards SC- $\beta$-cells. They unveiled genomic loci fundamental for the $\alpha$ - and $\beta$-cell lineage specification and regulatory circuits necessary for the differentiation towards $\beta$-cells. Finally, they stretched the importance of the circadian metabolic cycles as critical factors for the achievement of functional mature $\beta$-cells [164]. 
Despite the extensive steps taken forward in the last few years, it is still necessary to improve the current differentiation protocols. Among the most important topics that still need to be clarified, there is the safety of the usage of SC- $\beta$-cells in human clinical trials. It will be important to define a clear advanced therapeutic medicinal product with a defined number of SC- $\beta$-cells and, similarly, also SC- $\alpha$-cells that properly function upon transplantation. Furthermore, the time of survival of the graft is still under investigation to evaluate the realistic benefit from the transplantation. In addition, there is a lack of a standardized differentiation protocol that allows in generating $\alpha$ - and $\beta$-cells with constant efficiency and minimal percentage of progenitors and poly-hormonal cells, which likely requires sorting and isolation strategies. For the future, we foresee a standardization of the differentiation protocols that aim to obtain constant percentage of monohormonal, fully functional $\alpha$ - and $\beta$-cells capable of sensing and responding to glucose variations and shutting down insulin secretion to avoid hypoglycemia. In this regard, animal studies that are currently being conducted to map the physiological propaedeutic steps of $\beta$-cell maturation will help to optimize differentiation protocols to generate functional cells for transplantation.

\section{Concluding Remarks}

Over the last decade, major steps in understanding mechanisms underlying $\beta$-cell maturation and identity have been taken. Intensive studies in animal models have led to the identification of different molecular markers, functional features and signaling pathways that coordinate $\beta$-cell maturation and maintain their functional phenotype. Nevertheless, uncovering how maturation programs are regulated by developmental and physiological parameters such as gene regulatory networks, islet niche factors and diet changes is only at the beginning. Furthermore, there is a lack of understanding of the contribution of the microenvironment, such as islet architecture, innervation, and vascularization in the establishment of mature $\beta$-cells. A better understanding of processes that result in maturation of in vitro-derived $\beta$-cells as well as their loss of identity in diabetic models might identify common pathways and mechanisms for cell-replacement and regeneration, respectively. In terms of regeneration strategies, more studies are essential to identify the markers and paths that result in loss of $\beta$-cell identity for drug targeting to restore functional $\beta$-cell mass. In this respect, recent technological breakthroughs such as single-cell genomic and transcriptomic are undoubtedly helping to decipher the pathomechanisms of $\beta$-cell failure in patients with diabetes. These advancements together with feasibility of targeted delivery of peptides or small molecules might bring a hope to specifically target and recover the function of those $\beta$-cell populations that lost their characteristics.

Author Contributions: All authors contributed to researching data, discussion and writing of the content, and reviewing and editing the manuscript before submission.

Acknowledgments: The authors apologize to those whose work has not been cited due to limited space. The authors acknowledge the support of the Helmholtz Association (Helmholtz-Gemeinschaft), German Research Foundation (Deutsche Forschungsgemeinschaft) and German Center for Diabetes Research (Deutsches Zentrum für Diabetes Forschung, DZD e.V.). H.L. and M.B. acknowledge the financial support by the DZD NEXT funding.

Conflicts of Interest: The authors declare no conflict of interest.

\section{References}

1. Leslie, R.D.; Palmer, J.; Schloot, N.C.; Lernmark, A. Diabetes at the crossroads: Relevance of disease classification to pathophysiology and treatment. Diabetologia 2016, 59, 13-20. [CrossRef] [PubMed]

2. Nolan, C.J.; Prentki, M. Insulin resistance and insulin hypersecretion in the metabolic syndrome and type 2 diabetes: Time for a conceptual framework shift. Diabetes Vasc. Dis. Res. 2019, 16, 118-127. [CrossRef] [PubMed]

3. Mannucci, E. Insulin Therapy and Cancer in Type 2 Diabetes. ISRN Endocrinol. 2012, 2012, 1-12. [CrossRef] [PubMed]

4. Koliaki, C.; Liatis, S.; le Roux, C.W.; Kokkinos, A. The role of bariatric surgery to treat diabetes: Current challenges and perspectives. BMC Endocr. Disord. 2017, 17, 50. [CrossRef] [PubMed] 
5. Shapiro, A.M.J.; Lakey, J.R.T.; Ryan, E.A.; Korbutt, G.S.; Toth, E.; Warnock, G.L.; Kneteman, N.M.; Rajotte, R.V. Islet Transplantation in Seven Patients with Type 1 Diabetes Mellitus Using a Glucocorticoid-Free Immunosuppressive Regimen. N. Engl. J. Med. 2002, 343, 230-238. [CrossRef] [PubMed]

6. Rother, K.I.; Harlan, D.M. Challenges facing islet transplantation for the treatment of type 1 diabetes mellitus. J. Clin. Investig. 2004, 114, 877-883. [CrossRef] [PubMed]

7. Swisa, A.; Glaser, B.; Dor, Y. Metabolic stress and compromised identity of pancreatic beta cells. Front. Genet. 2017, 1-11. [CrossRef]

8. Jiang, W.J.; Peng, Y.C.; Yang, K.M. Cellular signaling pathways regulating $\beta$-cell proliferation as a promising therapeutic target in the treatment of diabetes (Review). Exp. Ther. Med. 2018, 16, 3275-3285. [CrossRef]

9. Ardestani, A.; Paroni, F.; Azizi, Z.; Kaur, S.; Khobragade, V.; Yuan, T.; Frogne, T.; Tao, W.; Oberholzer, J.; Pattou, F.; et al. MST1 is a key regulator of beta cell apoptosis and dysfunction in diabetes. Nat. Med. 2014, 20, 385-397. [CrossRef]

10. Muhammad, S.A.; Raza, W.; Nguyen, T.; Bai, B.; Wu, X.; Chen, J. Cellular signaling pathways in insulin resistance-systems biology analyses of microarray dataset reveals new drug target gene signatures of type 2 diabetes mellitus. Front. Physiol. 2017, 8, 1-15. [CrossRef]

11. Jaafar, R.; Tran, S.; Shah, A.; Sun, G.; Valdearcos, M.; Marchetti, P.; Masini, M.; Swisa, A.; Giacometti, S.; Bernal-Mizrachi, E.; et al. mTORC1 to AMPK switching underlies $\beta$-cell metabolic plasticity during maturation and diabetes. J. Clin. Investig. 2019, 129, 4124-4137. [CrossRef] [PubMed]

12. Aguayo-Mazzucato, C.; Andle, J.; Lee, T.B.; Midha, A.; Talemal, L.; Chipashvili, V.; Hollister-Lock, J.; van Deursen, J.; Weir, G.; Bonner-Weir, S. Acceleration of $\beta$ Cell Aging Determines Diabetes and Senolysis Improves Disease Outcomes. Cell Metab. 2019, 30, 129-142. [CrossRef] [PubMed]

13. Alismail, H.; Jin, S. Microenvironmental stimuli for proliferation of functional islet $\beta$-cells. Cell Biosci. 2014, 4, 1-10. [CrossRef] [PubMed]

14. Robertson, R.P.; Harmon, J.; Tran, P.O.; Tanaka, Y.; Takahashi, H. Glucose toxicity in $\beta$-cells: Type 2 diabetes, good radicals gone bad, and the glutathione connection. Diabetes 2003, 52, 581-587. [CrossRef]

15. Friedman, R.S.; Lindsay, R.S.; Lilly, J.K.; Nguyen, V.; Sorensen, C.M.; Jacobelli, J.; Krummel, M.F. An evolving autoimmune microenvironment regulates the quality of effector T cell restimulation and function. Proc. Natl. Acad. Sci. USA 2014, 111, 9223-9228. [CrossRef] [PubMed]

16. Kracht, M.J.L.; Zaldumbide, A.; Roep, B.O. Neoantigens and Microenvironment in Type 1 Diabetes: Lessons from Antitumor Immunity. Trends Endocrinol. Metab. 2016, 27, 353-362. [CrossRef] [PubMed]

17. Aguayo-Mazzucato, C.; Bonner-Weir, S. Pancreatic $\beta$ Cell Regeneration as a Possible Therapy for Diabetes. Cell Metab. 2018, 27, 57-67. [CrossRef]

18. Zhou, Q.; Melton, D.A. Pancreas regeneration. Nature 2018, 557, 351-358. [CrossRef]

19. Tritschler, S.; Theis, F.J.; Lickert, H.; Böttcher, A. Systematic single-cell analysis provides new insights into heterogeneity and plasticity of the pancreas. Mol. Metab. 2017, 6, 974-990. [CrossRef]

20. Zhong, F.; Jiang, Y. Endogenous Pancreatic $\beta$ Cell Regeneration: A Potential Strategy for the Recovery of $\beta$ Cell Deficiency in Diabetes. Front. Endocrinol. (Lausanne) 2019, 10, 1-14. [CrossRef]

21. Kieffer, T.J.; Woltjen, K.; Osafune, K.; Yabe, D.; Inagaki, N. Beta-cell replacement strategies for diabetes. J. Diabetes Investig. 2018, 9, 457-463. [CrossRef] [PubMed]

22. Sneddon, J.B.; Tang, Q.; Stock, P.; Bluestone, J.A.; Roy, S.; Desai, T.; Hebrok, M. Stem Cell Therapies for Treating Diabetes: Progress and Remaining Challenges. Cell Stem Cell 2018, 22, 810-823. [CrossRef] [PubMed]

23. Peloso, A.; Citro, A.; Zoro, T.; Cobianchi, L.; Kahler-Quesada, A.; Bianchi, C.M.; Andres, A.; Berishvili, E.; Piemonti, L.; Berney, T; et al. Regenerative medicine and diabetes: Targeting the extracellular matrix beyond the stem cell approach and encapsulation technology. Front. Endocrinol. (Lausanne) 2018, 9, 1-9. [CrossRef] [PubMed]

24. Nostro, M.C.; Sarangi, F.; Yang, C.; Holland, A.; Elefanty, A.G.; Stanley, E.G.; Greiner, D.L.; Keller, G. Efficient generation of NKX6-1+ pancreatic progenitors from multiple human pluripotent stem cell lines. Stem Cell Rep. 2015, 4, 591-604. [CrossRef]

25. Pagliuca, F.W.; Millman, J.R.; Gürtler, M.; Segel, M.; Van Dervort, A.; Ryu, J.H.; Peterson, Q.P.; Greiner, D.; Melton, D.A. Generation of functional human pancreatic $\beta$ cells in vitro. Cell 2014, 159, 428-439. [CrossRef]

26. Rezania, A.; Bruin, J.E.; Xu, J.; Narayan, K.; Fox, J.K.; O’Neil, J.J.; Kieffer, T.J. Enrichment of human embryonic stem cell-derived NKX6.1-Expressing pancreatic progenitor cells accelerates the maturation of insulin-secreting cells in vivo. Stem Cells 2013, 31, 2432-2442. [CrossRef] 
27. Russ, H.A.; Parent, A.V.; Ringler, J.J.; Hennings, T.G.; Nair, G.G.; Shveygert, M.; Guo, T.; Puri, S.; Haataja, L.; Cirulli, V.; et al. Controlled induction of human pancreatic progenitors produces functional beta-like cells in vitro. EMBO J. 2015, 34, 1759-1772. [CrossRef]

28. Bastidas-Ponce, A.; Tritschler, S.; Dony, L.; Scheibner, K.; Tarquis-Medina, M.; Salinno, C.; Schirge, S.; Burtscher, I.; Böttcher, A.; Theis, F.J.; et al. Comprehensive single cell mRNA profiling reveals a detailed roadmap for pancreatic endocrinogenesis. Development 2019, 146, 1-16. [CrossRef]

29. Mamidi, A.; Prawiro, C.; Seymour, P.A.; de Lichtenberg, K.H.; Jackson, A.; Serup, P.; Semb, H. Mechanosignalling via integrins directs fate decisions of pancreatic progenitors. Nature 2018, 564, 114-118. [CrossRef]

30. Bakhti, M.; Böttcher, A.; Lickert, H. Modelling the endocrine pancreas in health and disease. Nat. Rev. Endocrinol. 2019, 15, 155-171. [CrossRef]

31. Blum, B.; Hrvatin, S.; Schuetz, C.; Bonal, C.; Rezania, A.; Melton, D.A. Functional beta-cell maturation is marked by an increased glucose threshold and by expression of urocortin 3. Nat. Biotechnol. 2012, 30, 261-264. [CrossRef] [PubMed]

32. Pan, F.C.; Wright, C. Pancreas organogenesis: From bud to plexus to gland. Dev. Dyn. 2011, 240, 530-565. [CrossRef] [PubMed]

33. Bastidas-Ponce, A.; Scheibner, K.; Lickert, H.; Bakhti, M. Cellular and molecular mechanisms coordinating pancreas development. Development 2017, 144, 2873-2888. [CrossRef] [PubMed]

34. Brereton, M.F.; Iberl, M.; Shimomura, K.; Zhang, Q.; Adriaenssens, A.E.; Proks, P.; Spiliotis, I.I.; Dace, W.; Mattis, K.K.; Ramracheya, R.; et al. Reversible changes in pancreatic islet structure and function produced by elevated blood glucose. Nat. Commun. 2014, 5, 1-11. [CrossRef] [PubMed]

35. Chakravarthy, H.; Gu, X.; Enge, M.; Dai, X.; Wang, Y.; Damond, N.; Downie, C.; Liu, K.; Wang, J.; Xing, Y.; et al. Converting Adult Pancreatic Islet $\alpha$ Cells into $\beta$ Cells by Targeting Both Dnmt1 and Arx. Cell Metab. 2017, 25, 622-634. [CrossRef] [PubMed]

36. Weir, G.C.; Bonner-Weir, S. Five stages of evolving beta-cell dysfunction during progression to diabetes. Diabetes 2004, 53 (Suppl. 3), S16-S21. [CrossRef]

37. Liu, J.S.E.; Hebrok, M. All mixed up: Defining roles for $\beta$-cell subtypes in mature islets. Genes Dev. 2017, 31, 228-240. [CrossRef]

38. Gutierrez, G.D.; Gromada, J.; Sussel, L. Heterogeneity of the pancreatic beta cell. Front. Genet. 2017, 8, 1-9. [CrossRef]

39. Romer, A.I.; Sussel, L. Pancreatic islet cell development and regeneration. Curr. Opin. Endocrinol. Diabetes Obes. 2015, 22, 255-264. [CrossRef]

40. Nasteska, D.; Hodson, D.J. The role of beta cell heterogeneity in islet function and insulin release. J. Mol. Endocrinol. 2018, 61, R43-R60. [CrossRef]

41. Bonner-weir, S. Pancreatic $\beta$-cell heterogeneity revisited. Nature 1916, 535, 365-366. [CrossRef] [PubMed]

42. Roscioni, S.S.; Migliorini, A.; Gegg, M.; Lickert, H. Impact of islet architecture on $\beta$-cell heterogeneity, plasticity and function. Nat. Publ. Gr. 2016, 12, 695-709. [CrossRef] [PubMed]

43. Nair, G.; Hebrok, M. Islet formation in mice and men: Lessons for the generation of functional insulin-producing $\beta$-cells from human pluripotent stem cells. Curr. Opin. Genet. Dev. 2015, 32, 171-180. [CrossRef]

44. Shih, H.P.; Wang, A.; Sander, M. Pancreas organogenesis: From lineage determination to morphogenesis. Annu. Rev. Cell Dev. Biol. 2013, 29, 81-105. [CrossRef] [PubMed]

45. Jennings, R.E.; Berry, A.A.; Kirkwood-Wilson, R.; Roberts, N.A.; Hearn, T.; Salisbury, R.J.; Blaylock, J.; Hanley, K.P.; Hanley, N.A. Development of the human pancreas from foregut to endocrine commitment. Diabetes 2013, 62, 3514-3522. [CrossRef]

46. Bechard, M.E.; Bankaitis, E.D.; Hipkens, S.B.; Ustione, A.; Piston, D.W.; Yang, Y.P.; Magnuson, M.A.; Wright, C.V.E. Precommitment low-level neurog3 expression defines a long-lived mitotic endocrine-biased progenitor pool that drives production of endocrine-committed cells. Genes Dev. 2016, 30, 1852-1865. [CrossRef]

47. Wang, S.; Yan, J.; Anderson, D.A.; Xu, Y.; Kanal, M.C.; Cao, Z.; Wright, C.V.E.; Gu, G. Neurog3 gene dosage regulates allocation of endocrine and exocrine cell fates in the developing mouse pancreas. Dev. Biol. 2010, 339, 26-37. [CrossRef] 
48. Byrnes, L.E.; Wong, D.M.; Subramaniam, M.; Meyer, N.P.; Gilchrist, C.L.; Knox, S.M.; Tward, A.D.; Ye, C.J.; Sneddon, J.B. Lineage dynamics of murine pancreatic development at single-cell resolution. Nat. Commun. 2018, 9, 1-17. [CrossRef]

49. Johansson, K.A.; Dursun, U.; Jordan, N.; Gu, G.; Beermann, F.; Gradwohl, G.; Grapin-Botton, A. Temporal Control of Neurogenin3 Activity in Pancreas Progenitors Reveals Competence Windows for the Generation of Different Endocrine Cell Types. Dev. Cell 2007, 12, 457-465. [CrossRef]

50. Bankaitis, E.D.; Bechard, M.E.; Wright, C.V.E. Feedback control of growth, differentiation, and morphogenesis of pancreatic endocrine progenitors in an epithelial plexus niche. Genes Dev. 2015, 29, 2203-2216. [CrossRef]

51. Desgraz, R.; Herrera, P.L. Pancreatic neurogenin 3-expressing cells are unipotent islet precursors. Development 2009, 136, 3567-3574. [CrossRef] [PubMed]

52. Larsen, H.L.; Grapin-Botton, A. The molecular and morphogenetic basis of pancreas organogenesis. Semin. Cell Dev. Biol. 2017. [CrossRef] [PubMed]

53. Jennings, R.E.; Berry, A.A.; Gerrard, D.T.; Wearne, S.J.; Strutt, J.; Withey, S.; Chhatriwala, M.; Piper Hanley, K.; Vallier, L.; Bobola, N.; et al. Laser Capture and Deep Sequencing Reveals the Transcriptomic Programmes Regulating the Onset of Pancreas and Liver Differentiation in Human Embryos. Stem Cell Rep. 2017, 9, 1387-1394. [CrossRef] [PubMed]

54. Gu, G.; Dubauskaite, J.; Melton, D.A. Direct evidence for the pancreatic lineage: NGN3+ cells are islet progenitors and are distinct from duct progenitors. Development 2002, 129, 2447-2457. [PubMed]

55. Gradwohl, G.; Dierich, A.; LeMeur, M.; Guillemot, F. Neurogenin3 Is Required for the Development of the Four Endocrine Cell Lineages of the Pancreas. Proc. Natl. Acad. Sci. USA 2000, 97, 1607-1611. [CrossRef] [PubMed]

56. Collombat, P.; Mansouri, A.; Hecksher-sørensen, J.; Serup, P.; Krull, J.; Gradwohl, G.; Gruss, P. Opposing actions of Arx and Pax4 in endocrine pancreas development Opposing actions of Arx and Pax4 in endocrine pancreas development. Genes Dev. 2003, 17, 2591-2603. [CrossRef] [PubMed]

57. Arda, H.E.; Benitez, C.M.; Kim, S.K. Gene regulatory networks governing pancreas development. Dev. Cell 2013, 25, 5-13. [CrossRef]

58. Bramswig, N.C.; Kaestner, K.H. Transcriptional regulation of $\alpha$-cell differentiation. Diabetes Obes. Metab. 2011, 13, 13-20. [CrossRef]

59. Dassaye, R.; Naidoo, S.; Cerf, M.E. Transcription factor regulation of pancreatic organogenesis, differentiation and maturation. Islets 2016, 8, 13-34. [CrossRef]

60. Jensen, J. Gene Regulatory Factors in Pancreatic Development. Dev. Dyn. 2004, 229, 176-200. [CrossRef]

61. Jennings, R.E.; Berry, A.A.; Strutt, J.P.; Gerrard, D.T.; Hanley, N.A. Human pancreas development. Development 2015, 142, 3126-3137. [CrossRef] [PubMed]

62. Lango Allen, H.; Flanagan, S.E.; Shaw-Smith, C.; De Franco, E.; Akerman, I.; Caswell, R.; Ferrer, J.; Hattersley, A.T.; Ellard, S. GATA6 haploinsufficiency causes pancreatic agenesis in humans. Nat. Genet. 2012, 44, 20-22. [CrossRef] [PubMed]

63. Rezania, A.; Bruin, J.E.; Arora, P.; Rubin, A.; Batushansky, I.; Asadi, A.; O’Dwyer, S.; Quiskamp, N.; Mojibian, M.; Albrecht, T.; et al. Reversal of diabetes with insulin-producing cells derived in vitro from human pluripotent stem cells. Nat. Biotechnol. 2014, 32, 1121-1133. [CrossRef] [PubMed]

64. Velazco-Cruz, L.; Song, J.; Maxwell, K.G.; Goedegebuure, M.M.; Augsornworawat, P.; Hogrebe, N.J.; Millman, J.R. Acquisition of Dynamic Function in Human Stem Cell-Derived $\beta$ Cells. Stem Cell Rep. 2019, 12, 351-365. [CrossRef] [PubMed]

65. Bakhti, M.; Scheibner, K.; Tritschler, S.; Bastidas-ponce, A. Establishment of a high-resolution 3D modeling system for studying pancreatic epithelial cell biology in vitro. Mol. Metab. 2019, 30. [CrossRef]

66. Sharon, N.; Chawla, R.; Mueller, J.; Vanderhooft, J.; Whitehorn, L.J.; Rosenthal, B.; Gürtler, M.; Estanboulieh, R.R.; Shvartsman, D.; Gifford, D.K.; et al. A Peninsular Structure Coordinates Asynchronous Differentiation with Morphogenesis to Generate Pancreatic Islets. Cell 2019, 176, 790-804. [CrossRef]

67. Martens, G.A.; Motté, E.; Kramer, G.; Stangé, G.; Gaarn, L.W.; Hellemans, K.; Nielsen, J.H.; Aerts, J.M.; Ling, Z.; Pipeleers, D. Functional characteristics of neonatal rat $\beta$ cells with distinct markers. J. Mol. Endocrinol. 2013, 52, 11-28. [CrossRef]

68. Dore, A.B.; Magde, G.E.; Grogan, W.M.; Webb, S.R. Biphasic Development of Posnatal Mouse Pancreas. Neonatology 1981, 40, 209-217. [CrossRef] 
69. Bonner-Weir, S.; Aguayo-Mazzucato, C.; Weir, G.C. Dynamic development of the pancreas from birth to adulthood. Ups. J. Med. Sci. 2016, 121, 155-158. [CrossRef]

70. Stolovich-Rain, M.; Enk, J.; Vikesa, J.; Nielsen, F.; Saada, A.; Glaser, B.; Dor, Y. Weaning Triggers a Maturation Step of Pancreatic $\beta$ Cells. Dev. Cell 2015, 32, 535-545. [CrossRef]

71. Van Der Meulen, T.; Donaldson, C.J.; Cáceres, E.; Hunter, A.E.; Cowing-Zitron, C.; Pound, L.D.; Adams, M.W.; Zembrzycki, A.; Grove, K.L.; Huising, M.O. Urocortin3 mediates somatostatin-dependent negative feedback control of insulin secretion. Nat. Med. 2015, 21, 769-776. [CrossRef] [PubMed]

72. van der Meulen, T.; Xie, R.; Kelly, O.G.; Vale, W.W.; Sander, M.; Huising, M.O. Urocortin 3 Marks Mature Human Primary and Embryonic Stem Cell-Derived Pancreatic Alpha and Beta Cells. PLoS ONE 2012, 7, E52181. [CrossRef] [PubMed]

73. Huang, C.; Walker, E.M.; Dadi, P.K.; Hu, R.; Xu, Y.; Zhang, W.; Sanavia, T.; Mun, J.; Liu, J.; Nair, G.G.; et al. Synaptotagmin 4 Regulates Pancreatic $\beta$ Cell Maturation by Modulating the $\mathrm{Ca}^{2+}$ Sensitivity of Insulin Secretion Vesicles. Dev. Cell 2018, 45, 347-361. [CrossRef] [PubMed]

74. Rodnoi, P.; Rajkumar, M.; Moin, A.S.M.; Georgia, S.K.; Butler, A.E.; Dhawan, S. Neuropeptide Y expression marks partially differentiated $\beta$ cells in mice and humans. JCI Insight 2017, 2, 1-13. [CrossRef] [PubMed]

75. Whim, M.D. Pancreatic beta cells synthesize neuropeptide $Y$ and can rapidly release peptide co-transmitters. PLoS ONE 2011, 6, E19478. [CrossRef] [PubMed]

76. Hang, Y.; Stein, R. MafA and MafB activity in pancreatic $\beta$ cells. Trends Endocrinol. Metab. 2011, 22, 364-373. [CrossRef]

77. Artner, I.; Blanchi, B.; Raum, J.C.; Guo, M.; Kaneko, T.; Cordes, S.; Sieweke, M.; Stein, R. MafB is required for islet beta cell maturation. Proc. Natl. Acad. Sci. USA 2007, 104, 3853-3858. [CrossRef]

78. Artner, I.; Hang, Y.; Mazur, M.; Yamamoto, T.; Guo, M.; Lindner, J.; Magnuson, M.A.; Stein, R. MafA and MafB regulate genes critical to $\beta$-cells in a unique temporal manner. Diabetes 2010, 59, 2530-2539. [CrossRef]

79. Nishimura, W.; Takahashi, S.; Yasuda, K. MafA is critical for maintenance of the mature beta cell phenotype in mice. Diabetologia 2015, 58, 566-574. [CrossRef]

80. Nishimura, W.; Kondo, T.; Salameh, T.; El Khattabi, I.; Dodge, R.; Bonner-Weir, S.; Sharma, A. A switch from MafB to MafA expression accompanies differentiation to pancreatic $\beta$-cells. Dev. Biol. 2006, 293, 526-539. [CrossRef]

81. Cyphert, H.A.; Walker, E.M.; Hang, Y.; Dhawan, S.; Haliyur, R.; Bonatakis, L.; Avrahami, D.; Brissova, M.; Kaestner, K.H.; Bhushan, A.; et al. Examining how the MAFB transcription factor affects islet $\beta$-cell function postnatally. Diabetes 2019, 68, 337-348. [CrossRef] [PubMed]

82. Morán, I.; Akerman, I.; Van De Bunt, M.; Xie, R.; Benazra, M.; Nammo, T.; Arnes, L.; Nakić, N.; García-Hurtado, J.; Rodríguez-Seguí, S.; et al. Human $\beta$ cell transcriptome analysis uncovers lncRNAs that are tissue-specific, dynamically regulated, and abnormally expressed in type 2 diabetes. Cell Metab. 2012, 16, 435-448. [CrossRef] [PubMed]

83. Akerman, I.; Tu, Z.; Beucher, A.; Rolando, D.M.Y.; Sauty-Colace, C.; Benazra, M.; Nakic, N.; Yang, J.; Wang, H.; Pasquali, L.; et al. Human Pancreatic $\beta$ Cell lncRNAs Control Cell-Specific Regulatory Networks. Cell Metab. 2017, 25, 400-411. [CrossRef] [PubMed]

84. Gegg, M.; Böttcher, A.; Burtscher, I.; Hasenoeder, S.; Van Campenhout, C.; Aichler, M.; Walch, A.; Grant, S.G.N.; Lickert, H. Flattop regulates basal body docking and positioning in mono- and multiciliated cells. Elife 2014, 3, 1-24. [CrossRef]

85. Bader, E.; Migliorini, A.; Gegg, M.; Moruzzi, N.; Gerdes, J.; Roscioni, S.S.; Bakhti, M.; Brandl, E.; Irmler, M.; Beckers, J.; et al. Identification of proliferative and mature $\beta$-cells in the islets of Langerhans. Nature 2016, 535, 430-434. [CrossRef]

86. Dorrell, C.; Schug, J.; Canaday, P.S.; Russ, H.A.; Tarlow, B.D.; Grompe, M.T.; Horton, T.; Hebrok, M.; Streeter, P.R.; Kaestner, K.H.; et al. Human islets contain four distinct subtypes of $\beta$ cells. Nat. Commun. 2016, 7, 1-9. [CrossRef]

87. Johnston, N.R.; Mitchell, R.K.; Haythorne, E.; Pessoa, M.P.; Semplici, F.; Ferrer, J.; Piemonti, L.; Marchetti, P.; Bugliani, M.; Bosco, D.; et al. Beta Cell Hubs Dictate Pancreatic Islet Responses to Glucose. Cell Metab. 2016, 24, 389-401. [CrossRef]

88. van der Meulen, T.; Mawla, A.M.; DiGruccio, M.R.; Adams, M.W.; Nies, V.; Dólleman, S.; Liu, S.; Ackermann, A.M.; Cáceres, E.; Hunter, A.E.; et al. Virgin Beta Cells Persist throughout Life at a Neogenic Niche within Pancreatic Islets. Cell Metab. 2017, 25, 911-926. [CrossRef] 
89. Kulkarni, R.N.; Mizrachi, E.-B.; Ocana, A.G.; Stewart, A.F. Human $\beta$-cell proliferation and intracellular signaling: Driving in the dark without a road map. Diabetes 2012, 61, 2205-2213. [CrossRef]

90. Bernal-Mizrachi, E.; Kulkarni, R.N.; Scott, D.K.; Mauvais-Jarvis, F.; Stewart, A.F.; Garcia-Ocaña, A. Human $\beta$-cell proliferation and intracellular signaling part 2: Still driving in the dark without a road map. Diabetes 2014, 63, 819-831. [CrossRef]

91. Stewart, A.F.; Hussain, M.A.; García-Ocaña, A.; Vasavada, R.C.; Bhushan, A.; Bernal-Mizrachi, E.; Kulkarni, R.N. Human $\beta$-Cell proliferation and intracellular signaling: Part 3. Diabetes 2015, 64, 1872-1885. [CrossRef] [PubMed]

92. Baeyens, L.; Hindi, S.; Sorenson, R.L.; German, M.S. $\beta$-Cell adaptation in pregnancy. Diabetes Obes. Metab. 2016, 18, 63-70. [CrossRef] [PubMed]

93. Arrojo e Drigo, R.; Lev-Ram, V.; Tyagi, S.; Ramachandra, R.; Deerinck, T.; Bushong, E.; Phan, S.; Orphan, V.; Lechene, C.; Ellisman, M.H.; et al. Age Mosaicism across Multiple Scales in Adult Tissues. Cell Metab. 2019, 30, 343-351. [CrossRef] [PubMed]

94. Linnemann, A.K.; Baan, M.; Davis, D.B. Pancreatic -Cell Proliferation in Obesity. Adv. Nutr. An Int. Rev. J. 2014, 5, 278-288. [CrossRef] [PubMed]

95. Piccand, J.; Meunier, A.; Merle, C.; Jia, Z.; Barnier, J.V.; Gradwohl, G. Pak3 promotes cell cycle exit and differentiation of $\beta$-cells in the embryonic pancreas and is necessary to maintain glucose homeostasis in adult mice. Diabetes 2014, 63, 203-215. [CrossRef]

96. Puri, S.; Roy, N.; Russ, H.A.; Leonhardt, L.; French, E.K.; Roy, R.; Bengtsson, H.; Scott, D.K.; Stewart, A.F.; Hebrok, M. Replication confers $\beta$ cell immaturity. Nat. Commun. 2018, 9, 1-12. [CrossRef]

97. Shirakawa, J.; Kulkarni, R.N. Novel factors modulating human $\beta$-cell proliferation. Diabetes Obes. Metab. 2016, 18, 71-77. [CrossRef]

98. Kang, T.; Jensen, P.; Huang, H.; Lund Christensen, G.; Billestrup, N.; Larsen, M.R. Characterization of the Molecular Mechanisms Underlying Glucose Stimulated Insulin Secretion from Isolated Pancreatic $\beta$-cells Using Post-translational Modification Specific Proteomics (PTMomics). Mol. Cell. Proteom. 2018, 17, 95-110. [CrossRef]

99. Meda, P.; Schuit, F. Glucose-stimulated insulin secretion: The hierarchy of its multiple cellular and subcellular mechanisms. Diabetologia 2013, 56, 2552-2555. [CrossRef]

100. Jensen, M.V.; Joseph, J.W.; Ronnebaum, S.M.; Burgess, S.C.; Sherry, A.D.; Newgard, C.B. Metabolic cycling in control of glucose-stimulated insulin secretion. Am. J. Physiol. Metab. 2008, 295, E1287-E1297. [CrossRef]

101. Maechler, P. Mitochondrial function and insulin secretion. Mol. Cell. Endocrinol. 2013, 379, 12-18. [CrossRef] [PubMed]

102. Nicholls, D.G. The Pancreatic $\beta$-Cell: A Bioenergetic Perspective. Physiol. Rev. 2016, 96, 1385-1447. [CrossRef] [PubMed]

103. Rorsman, P.; Ashcroft, F.M. Pancreatic $\beta$-Cell Electrical Activity and Insulin Secretion: Of Mice and Men. Physiol. Rev. 2017, 98, 117-214. [CrossRef] [PubMed]

104. Jermendy, A.; Toschi, E.; Aye, T.; Koh, A.; Aguayo-Mazzucato, C.; Sharma, A.; Weir, G.C.; Sgroi, D.; Bonner-Weir, S. Rat neonatal beta cells lack the specialised metabolic phenotype of mature beta cells. Diabetologia 2011, 54, 594-604. [CrossRef]

105. Wortham, M.; Benthuysen, J.R.; Wallace, M.; Savas, J.N.; Mulas, F.; Divakaruni, A.S.; Liu, F.; Albert, V.; Taylor, B.L.; Sui, Y.; et al. Integrated In Vivo Quantitative Proteomics and Nutrient Tracing Reveals Age-Related Metabolic Rewiring of Pancreatic $\beta$ Cell Function. Cell Rep. 2018, 25, 2904-2918. [CrossRef]

106. Henquin, J.C.; Nenquin, M. Immaturity of insulin secretion by pancreatic islets isolated from one human neonate. J. Diabetes Investig. 2018, 9, 270-273. [CrossRef]

107. Wang, Z.; Thurmond, D.C. Mechanisms of biphasic insulin-granule exocytosis-Roles of the cytoskeleton, small GTPases and SNARE proteins. J. Cell Sci. 2009, 122, 893-903. [CrossRef]

108. Salem, V.; Silva, L.D.; Suba, K.; Georgiadou, E.; Neda Mousavy Gharavy, S.; Akhtar, N.; Martin-Alonso, A.; Gaboriau, D.C.A.; Rothery, S.M.; Stylianides, T.; et al. Leader $\beta$-cells coordinate $\mathrm{Ca}^{2+}$ dynamics across pancreatic islets in vivo. Nat. Metab. 2019, 1, 615-629. [CrossRef]

109. Lei, C.L.; Kellard, J.A.; Hara, M.; Johnson, J.D.; Rodriguez, B.; Briant, L.J.B. Beta-cell hubs maintain Ca ${ }^{2+}$ oscillations in human and mouse islet simulations. Islets 2018, 10, 151-167. [CrossRef]

110. Saxton, R.A.; Sabatini, D.M. mTOR Signaling in Growth, Metabolism, and Disease. Cell 2017, 361-371. [CrossRef] 
111. Sinagoga, K.L.; Stone, W.J.; Schiesser, J.V.; Schweitzer, J.I.; Sampson, L.; Zheng, Y.; Wells, J.M. Distinct roles for the mTOR pathway in postnatal morphogenesis, maturation and function of pancreatic islets. J. Cell Sci. 2017, 144, 2402-2414.

112. Ni, Q.; Gu, Y.; Xie, Y.; Yin, Q.; Zhang, H.; Nie, A.; Li, W.; Wang, Y.; Ning, G.; Wang, W.; et al. Raptor regulates functional maturation of murine beta cells. Nat. Commun. 2017, 8, 1-13. [CrossRef] [PubMed]

113. Lin, S.C.; Hardie, D.G. AMPK: Sensing Glucose as well as Cellular Energy Status. Cell Metab. 2018, 27, 299-313. [CrossRef] [PubMed]

114. Fu, A.; Eberhard, C.E.; Screaton, R.A. Role of AMPK in pancreatic beta cell function. Mol. Cell. Endocrinol. 2013, 366, 127-134. [CrossRef]

115. Rourke, J.L.; Hu, Q.; Screaton, R.A. AMPK and Friends: Central Regulators of $\beta$ Cell Biology. Trends Endocrinol. Metab. 2018, 29, 111-122. [CrossRef]

116. Yoshihara, E.; Wei, Z.; Lin, C.S.; Fang, S.; Ahmadian, M.; Kida, Y.; Tseng, T.; Dai, Y.; Yu, R.T.; Liddle, C.; et al. ERR $\gamma$ Is Required for the Metabolic Maturation of Therapeutically Functional Glucose-Responsive $\beta$ Cells. Cell Metab. 2016, 23, 622-643. [CrossRef]

117. Sharon, N.; Vanderhooft, J.; Straubhaar, J.; Mueller, J.; Chawla, R.; Zhou, Q.; Engquist, E.N.; Trapnell, C.; Gifford, D.K.; Melton, D.A. Wnt Signaling Separates the Progenitor and Endocrine Compartments during Pancreas Development. Cell Rep. 2019, 27, 2281-2291. [CrossRef]

118. Cortijo, C.; Gouzi, M.; Tissir, F.; Grapin-Botton, A. Planar Cell Polarity Controls Pancreatic Beta Cell Differentiation and Glucose Homeostasis. Cell Rep. 2012, 2, 1593-1606. [CrossRef]

119. Scheibner, K.; Bakhti, M.; Bastidas-Ponce, A.; Lickert, H. Wnt signaling: Implications in endoderm development and pancreas organogenesis. Curr. Opin. Cell Biol. 2019, 61, 48-55. [CrossRef]

120. Liu, X.; Yan, F.; Yao, H.; Chang, M.; Qin, J.; Li, Y.; Wang, Y.; Pei, X. Involvement of RhoA/ROCK in insulin secretion of pancreatic $\beta$-cells in 3D culture. Cell Tissue Res. 2014, 358, 359-369. [CrossRef]

121. Schulze, T.; Morsi, M.; Brüning, D.; Schumacher, K.; Rustenbeck, I. Different responses of mouse islets and MIN6 pseudo-islets to metabolic stimulation: A note of caution. Endocrine 2016, 51, 440-447. [CrossRef] [PubMed]

122. Carstensen-Kirberg, M.; Röhrig, K.; Niersmann, C.; Margriet Ouwens, D.; Belgardt, B.F.; Roden, M.; Herder, C. Sfrp5 increases glucose-stimulated insulin secretion in the rat pancreatic beta cell line INS-1E. PLoS ONE 2019, 14, e0213650. [CrossRef] [PubMed]

123. Ardestani, A.; Maedler, K. The Hippo signaling pathway in pancreatic $\beta$-cells: Functions and regulations. Endocr. Rev. 2018, 39, 21-35. [CrossRef] [PubMed]

124. Guo, S.; Dai, C.; Guo, M.; Taylor, B.; Harmon, J.S.; Sander, M.; Robertson, R.P.; Powers, A.C.; Stein, R. Inactivation of specific $\beta$ cell transcription factors in type 2 diabetes. J. Clin. Investig. 2013, 123, 3305-3316. [CrossRef]

125. Bensellam, M.; Jonas, J.C.; Laybutt, D.R. Mechanisms of $\beta$;-cell dedifferentiation in diabetes: Recent findings and future research directions. J. Endocrinol. 2018, 236, R109-R143. [CrossRef]

126. Dahan, T.; Ziv, O.; Horwitz, E.; Zemmour, H.; Lavi, J.; Swisa, A.; Leibowitz, G.; Ashcroft, F.M.; In't Veld, P.; Glaser, B.; et al. Pancreatic $\beta$-Cells express the fetal islet hormone gastrin in rodent and human diabetes. Diabetes 2017, 66, 426-436. [CrossRef]

127. Jonas, J.C.; Sharma, A.; Hasenkamp, W.; Ilkova, H.; Patanè, G.; Laybutt, R.; Bonner-Weir, S.; Weir, G.C. Chronic hyperglycemia triggers loss of pancreatic beta cell differentiation in an animal model of diabetes. J. Biol. Chem. 1999, 274, 14112-14121. [CrossRef]

128. Ross Laybutt, D.; Sharma, A.; Sgroi, D.C.; Gaudet, J.; Bonner-Weir, S.; Weir, G.C. Genetic regulation of metabolic pathways in $\beta$-cells disrupted by hyperglycemia. J. Biol. Chem. 2002, 277, 10912-10921. [CrossRef]

129. Laybutt, D.R.; Glandt, M.; Xu, G.; Ahn, Y.B.; Trivedi, N.; Bonner-Weir, S.; Weir, G.C. Critical reduction $\beta$-cell mass results in two distinct outcomes over time. Adaptation with impaired glucose tolerance or decompensated diabetes. J. Biol. Chem. 2003, 278, 2997-3005. [CrossRef]

130. Talchai, C.; Xuan, S.; Lin, H.V.; Sussel, L.; Accili, D. Pancreatic $\beta$ cell dedifferentiation as a mechanism of diabetic $\beta$ cell failure. Cell 2012, 150, 1223-1234. [CrossRef]

131. Wang, Z.; York, N.W.; Nichols, C.G.; Remedi, M.S. Pancreatic $\beta$ cell dedifferentiation in diabetes and redifferentiation following insulin therapy. Cell Metab. 2014, 19, 872-882. [CrossRef] [PubMed] 
132. Diedisheim, M.; Oshima, M.; Albagli, O.; Huldt, C.W.; Ahlstedt, I.; Clausen, M.; Menon, S.; Aivazidis, A.; Andreasson, A.C.; Haynes, W.G.; et al. Modeling human pancreatic beta cell dedifferentiation. Mol. Metab. 2018, 10, 74-86. [CrossRef] [PubMed]

133. Lam, C.J.; Chatterjee, A.; Shen, E.; Cox, A.R.; Kushner, J.A. Low-level insulin content within abundant non-b islet endocrine cells in long-standing type 1 diabetes. Diabetes 2019, 68, 598-608. [CrossRef] [PubMed]

134. Cinti, F.; Bouchi, R.; Kim-Muller, J.Y.; Ohmura, Y.; Sandoval, P.R.; Masini, M.; Marselli, L.; Suleiman, M.; Ratner, L.E.; Marchetti, P.; et al. Evidence of $\beta$-cell dedifferentiation in human type 2 diabetes. J. Clin. Endocrinol. Metab. 2016, 101, 1044-1054. [CrossRef] [PubMed]

135. Rui, J.; Deng, S.; Arazi, A.; Perdigoto, A.L.; Liu, Z.; Herold, K.C. $\beta$ Cells that Resist Immunological Attack Develop during Progression of Autoimmune Diabetes in NOD Mice. Cell Metab. 2017, 25, 727-738. [CrossRef] [PubMed]

136. Keenan, H.A.; Sun, J.K.; Levine, J.; Doria, A.; Aiello, L.P.; Eisenbarth, G.; Bonner-Weir, S.; King, G.L. Residual insulin production and pancreatic $\beta$-cell turnover after 50 years of diabetes: Joslin medalist study. Diabetes 2010, 59, 2846-2853. [CrossRef]

137. Spaeth, J.M.; Gupte, M.; Perelis, M.; Yang, Y.P.; Cyphert, H.; Guo, S.; Liu, J.H.; Guo, M.; Bass, J.; Magnuson, M.A.; et al. Defining a Novel Role for the Pdx1 Transcription Factor in Islet $\beta$-Cell Maturation and Proliferation During Weaning. Diabetes 2017, 66, 2830-2839. [CrossRef]

138. Bastidas-Ponce, A.; Roscioni, S.S.; Burtscher, I.; Bader, E.; Sterr, M.; Bakhti, M.; Lickert, H. Foxa2 and Pdx1 cooperatively regulate postnatal maturation of pancreatic $\beta$-cells. Mol. Metab. 2017, 6, 524-534. [CrossRef]

139. Sacco, F.; Seelig, A.; Humphrey, S.J.; Krahmer, N.; Volta, F.; Reggio, A.; Marchetti, P.; Gerdes, J.; Mann, M. Phosphoproteomics Reveals the GSK3-PDX1 Axis as a Key Pathogenic Signaling Node in Diabetic Islets. Cell Metab. 2019, 29, 1422-1432. [CrossRef]

140. Cheng, C.W.; Villani, V.; Buono, R.; Wei, M.; Kumar, S.; Yilmaz, O.H.; Cohen, P.; Sneddon, J.B.; Perin, L.; Longo, V.D. Fasting-Mimicking Diet Promotes Ngn3-Driven $\beta$-Cell Regeneration to Reverse Diabetes. Cell 2017, 168, 775-788. [CrossRef]

141. Tomita, T. Apoptosis of pancreatic $\beta$-cells in Type 1 diabetes. Bosn. J. Basic Med. Sci. 2017, 17, $183-193$. [CrossRef] [PubMed]

142. Tomita, T. Apoptosis in pancreatic $\beta$-islet cells in Type 2 diabetes. Bosn. J. Basic Med. Sci. 2016, 16, 162-179. [CrossRef] [PubMed]

143. Meier, J.J.; Bhushan, A.; Butler, A.E.; Rizza, R.A.; Butler, P.C. Sustained beta cell apoptosis in patients with long-standing type 1 diabetes: Indirect evidence for islet regeneration? Diabetologia 2005, 48, 2221-2228. [CrossRef] [PubMed]

144. Thomas, H.E.; McKenzie, M.D.; Angstetra, E.; Campbell, P.D.; Kay, T.W. Beta cell apoptosis in diabetes. Apoptosis 2009, 14, 1389-1404. [CrossRef] [PubMed]

145. Weir, G.C.; Bonner-Weir, S. Islet $\beta$ cell mass in diabetes and how it relates to function, birth, and death. Ann. N. Y. Acad. Sci. 2013, 1281, 92-105. [CrossRef] [PubMed]

146. Weir, G.C.; Aguayo-Mazzucato, C.; Bonner-Weir, S. $\beta$-cell dedifferentiation in diabetes is important, but what is it? Islets 2013, 5, 233-237. [CrossRef] [PubMed]

147. Chera, S.; Baronnier, D.; Ghila, L.; Cigliola, V.; Jensen, J.N.; Gu, G.; Furuyama, K.; Thorel, F.; Gribble, F.M.; Reimann, F.; et al. Diabetes recovery by age-dependent conversion of pancreatic $\delta$-cells into insulin producers. Nature 2014, 514, 503-507. [CrossRef]

148. Moin, A.S.; Butler, A.E. Alterations in Beta Cell Identity in Type 1 and Type 2 Diabetes. Curr. Diab. Rep. 2019, 19, 83. [CrossRef]

149. Gutiérrez, G.D.; Bender, A.S.; Cirulli, V.; Mastracci, T.L.; Kelly, S.M.; Tsirigos, A.; Kaestner, K.H.; Sussel, L. Pancreatic $\beta$ cell identity requires continual repression of non- $\beta$ cell programs. J. Clin. Investig. 2017, 127, 244-259. [CrossRef]

150. Gao, T.; McKenna, B.; Li, C.; Reichert, M.; Nguyen, J.; Singh, T.; Yang, C.; Pannikar, A.; Doliba, N.; Zhang, T.; et al. Pdx1 maintains $\beta$ cell identity and function by repressing an $\alpha$ cell program. Cell Metab. 2014, 19, 259-271. [CrossRef]

151. Seiron, P.; Wiberg, A.; Kuric, E.; Krogvold, L.; Jahnsen, F.L.; Dahl-Jørgensen, K.; Skog, O.; Korsgren, O. Characterisation of the endocrine pancreas in type 1 diabetes: Islet size is maintained but islet number is markedly reduced. J. Pathol. Clin. Res. 2019, 5, 248-255. [CrossRef] [PubMed] 
152. Dirice, E.; Kahraman, S.; De Jesus, D.F.; El Ouaamari, A.; Basile, G.; Baker, R.L.; Yigit, B.; Piehowski, P.D.; Kim, M.-J.; Dwyer, A.J.; et al. Increased $\beta$-cell proliferation before immune cell invasion prevents progression of type 1 diabetes. Nat. Metab. 2019, 1, 509-518. [CrossRef] [PubMed]

153. Thorel, F.; Népote, V.; Avril, I.; Kohno, K.; Desgraz, R.; Chera, S.; Herrera, P.L. Conversion of adult pancreatic alpha-cells to beta-cells after extreme beta-cell loss. Nature 2010, 464, 1149-1154. [CrossRef] [PubMed]

154. Furuyama, K.; Chera, S.; van Gurp, L.; Oropeza, D.; Ghila, L.; Damond, N.; Vethe, H.; Paulo, J.A.; Joosten, A.M.; Berney, T.; et al. Diabetes relief in mice by glucose-sensing insulin-secreting human $\alpha$-cells. Nature 2019, 567, 43-48. [CrossRef] [PubMed]

155. Bakhti, M.; Lickert, H. Cell makeover for diabetes therapy. Nat. Metab. 2019, 1, 312-313. [CrossRef]

156. Aguayo-Mazzucato, C.; van Haaren, M.; Mruk, M.; Lee, T.B.; Crawford, C.; Hollister-Lock, J.; Sullivan, B.A.; Johnson, J.W.; Ebrahimi, A.; Dreyfuss, J.M.; et al. $\beta$ Cell Aging Markers Have Heterogeneous Distribution and Are Induced by Insulin Resistance. Cell Metab. 2017, 25, 898-910. [CrossRef]

157. Thompson, P.J.; Shah, A.; Ntranos, V.; Van Gool, F.; Atkinson, M.; Bhushan, A. Targeted Elimination of Senescent Beta Cells Prevents Type 1 Diabetes. Cell Metab. 2019, 29, 1045-1060. [CrossRef]

158. Mills, J.C.; Stanger, B.Z.; Sander, M. Nomenclature for cellular plasticity: Are the terms as plastic as the cells themselves? EMBO J. 2019, 38, 1-5. [CrossRef]

159. Shahjalal, H.M.; Abdal Dayem, A.; Lim, K.M.; Jeon, T.-I.; Cho, S.G. Generation of pancreatic $\beta$ cells for treatment of diabetes: Advances and challenges. Stem Cell Res. Ther. 2018, 9, 1-19. [CrossRef]

160. Nair, G.G.; Liu, J.S.; Russ, H.A.; Tran, S.; Saxton, M.S.; Chen, R.; Juang, C.; Li, M.-L.; Nguyen, V.Q.; Giacometti, S.; et al. Recapitulating endocrine cell clustering in culture promotes maturation of human stem-cell-derived $\beta$ cells. Nat. Cell Biol. 2019, 21, 263-274. [CrossRef]

161. Alagpulinsa, D.A.; Cao, J.J.L.; Driscoll, R.K.; Sîrbulescu, R.F.; Penson, M.F.E.; Sremac, M.; Engquist, E.N.; Brauns, T.A.; Markmann, J.F.; Melton, D.A.; et al. Alginate-microencapsulation of human stem cell-derived $\beta$ cells with CXCL12 prolongs their survival and function in immunocompetent mice without systemic immunosuppression. Am. J. Transplant. 2019, 19, 1930-1940. [PubMed]

162. Veres, A.; Faust, A.L.; Bushnell, H.L.; Engquist, E.N.; Kenty, J.H.R.; Harb, G.; Poh, Y.C.; Sintov, E.; Gürtler, M.; Pagliuca, F.W.; et al. Charting cellular identity during human in vitro $\beta$-cell differentiation. Nature 2019, 569, 368-373. [CrossRef] [PubMed]

163. Theis, F.J.; Lickert, H. A map of $\beta$-cell differentiation pathways supports cell therapies for diabetes. Nature 2019, 569, 342-343. [CrossRef] [PubMed]

164. Alvarez-Dominguez, J.R.; Donaghey, J.; Kenty, J.H.R.; Rasouli, N.; Helman, A.; Charlton, J.; Straubhaar, J.R.; Meissner, A.; Melton, D.A. Dissecting mechanisms of human islet differentiation and maturation through epigenome profiling. bioRxiv Genom. 2019, 4, 613026. 